\title{
Environmental Consequences of the Retsof Salt Mine Roof Collapse
}

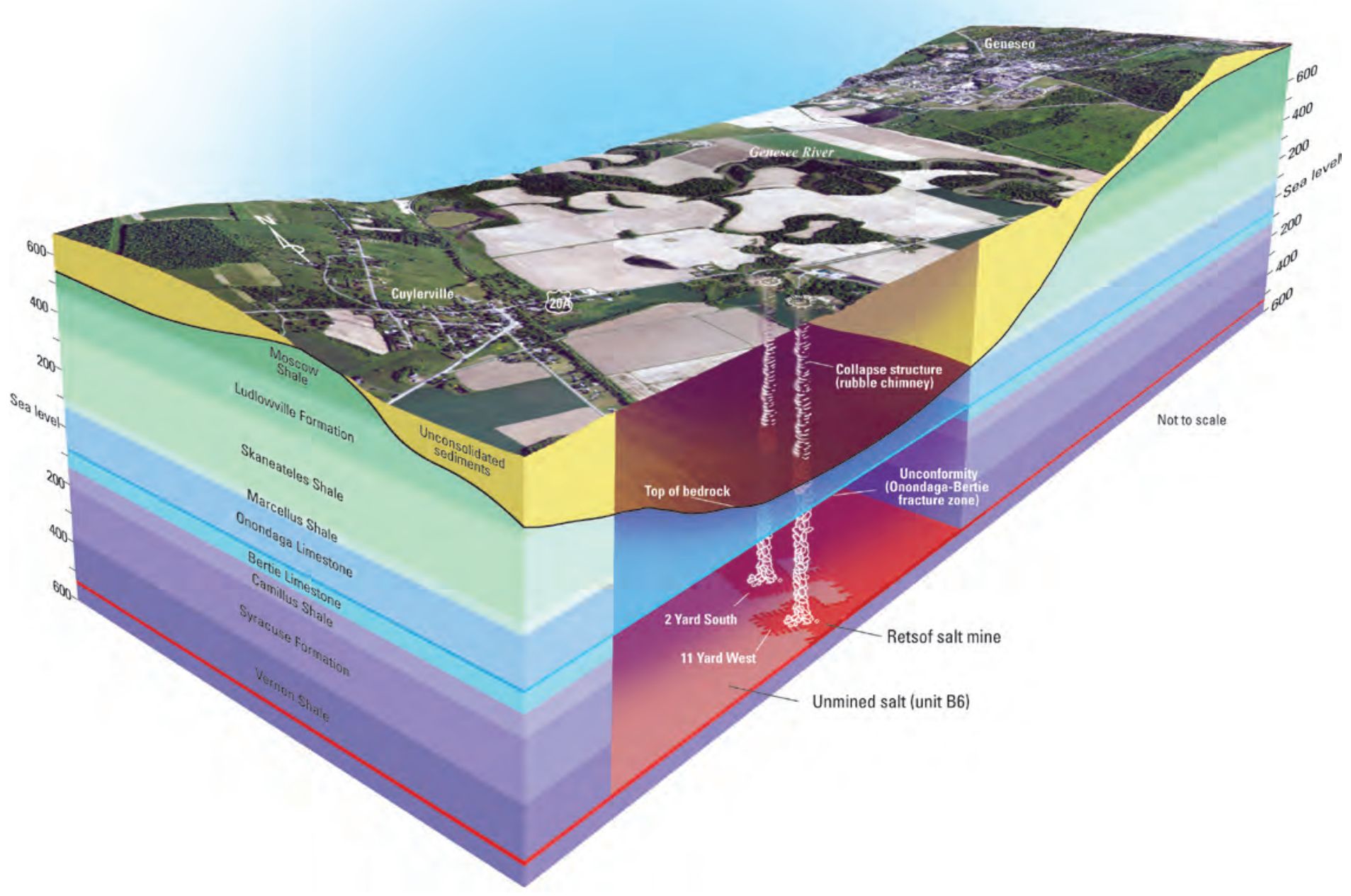

Open-File Report 2013-1174

U.S. Department of the Interior

U.S. Geological Survey 
Cover. Perspective three-dimensional views showing the geologic setting and the unconsolidated sediments in the area of the Retsof salt mine in Livingston County, New York. 


\section{Environmental Consequences of the Retsof Salt Mine Roof Collapse}

By Richard M. Yager

Open File Report 2013-1174 


\section{U.S. Department of the Interior \\ SALLY JEWELL, Secretary}

\section{U.S. Geological Survey \\ Suzette M. Kimball, Acting Director}

U.S. Geological Survey, Reston, Virginia: 2013

For more information on the USGS - the Federal source for science about the Earth, its natural and living resources, natural hazards, and the environment, visit http://www.usgs.gov or call 1-888-ASK-USGS.

For an overview of USGS information products, including maps, imagery, and publications, visit http://www.usgs.gov/pubprod

To order this and other USGS information products, visit http://store.usgs.gov

Any use of trade, firm, or product names is for descriptive purposes only and does not imply endorsement by the U.S. Government.

Although this information product, for the most part, is in the public domain, it also may contain copyrighted materials as noted in the text. Permission to reproduce copyrighted items must be secured from the copyright owner.

Suggested citation:

Yager, R.M., 2013, Environmental consequences of the Retsof Salt Mine roof collapse: U.S. Geological Survey OpenFile Report 2013-1174, 10 p., http://pubs.usgs.gov/of/2013/1174/. 


\section{Contents}

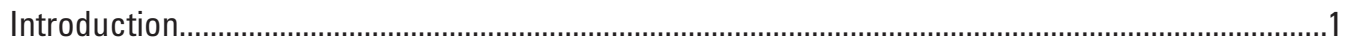

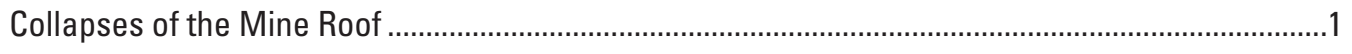

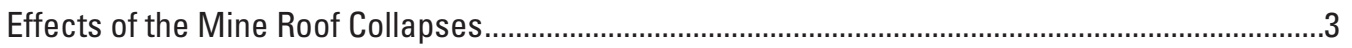

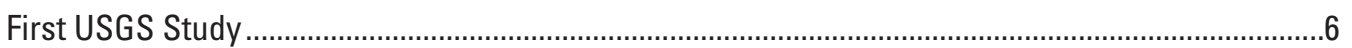

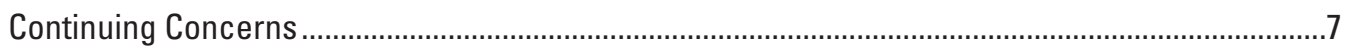

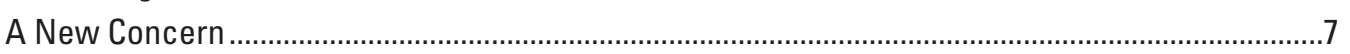

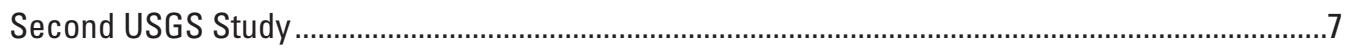

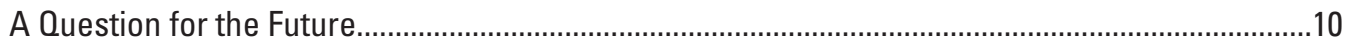

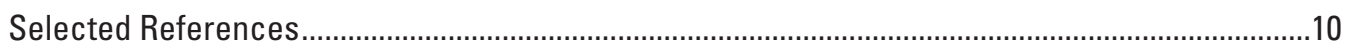

\section{Figures}

1. Map showing the location of the former Retsof salt mine and area of roof collapse in Livingston County, New York

2. Perspective three-dimensional views showing the geologic setting and the unconsolidated sediments in the area of the Retsof salt mine in Livingston County, New York

3. Graphs showing environmental changes in the aquifer system near the collapsed Retsof salt mine in Livingston County, New York, from 1994 through 2006.

4. Schematic diagram of the salinity profile along cross-section $A-A^{\prime}$, as percent saturation with respect to halite, in the collapse area at the Retsof salt mine in Livingston County, New York, in September 2006.

5. Map showing the extent of saline water in the lower confined aquifer 8 years after cessation of pumping in the collapse area as predicted by numerical simulation

\section{Abbreviations}

ANSI AkzoNobel Salt Incorporated

USGS U.S. Geological Survey 
This page has been left blank intentionally. 


\title{
Environmental Consequences of the Retsof Salt Mine Roof Collapse
}

\author{
By Richard M. Yager
}

\section{Introduction}

In 1994, the largest salt mine in North America, which had been in operation for more than 100 years, catastrophically flooded when the mine ceiling collapsed (fig. 1). In addition to causing the loss of the mine and the mineral resources it provided, this event formed sinkholes, caused widespread subsidence to land, caused structures to crack and subside, and changed stream flow and erosion patterns. Subsequent flooding of the mine drained overlying aquifers, changed the groundwater salinity distribution (rendering domestic wells unusable), and allowed locally present natural gas to enter dwellings through water wells. Investigations including exploratory drilling, hydrologic and water-quality monitoring, geologic and geophysical studies, and numerical simulation of groundwater flow, salinity, and subsidence have been effective tools in understanding the environmental consequences of the mine collapse and informing decisions about management of those consequences for the future.

Salt mines are generally dry, but are susceptible to leaks and can become flooded if groundwater from overlying aquifers or surface water finds a way downward into the mined cavity through hundreds of feet of rock. With its potential to flood the entire mine cavity, groundwater is a constant source of concern for mine operators. The problem is compounded by the viscous nature of salt and the fact that salt mines commonly lie beneath water-bearing aquifers. Salt (for example halite or potash) deforms and "creeps" into the mined openings over time spans that range from years to centuries. This movement of salt can destabilize the overlying rock layers and lead to their eventual sagging and collapse, creating permeable pathways for leakage of water and depressions or openings at land surface, such as sinkholes. Salt is also highly soluble in water; therefore, whenever water begins to flow into a salt mine, the channels through which it flows increase in diameter as the surrounding salt dissolves. Some mines leak at a slow rate for decades before a section of rock gives way, allowing what initially was a trickle of water to suddenly become a cascade and finally a torrent. Other mines become flooded and are destroyed when an errant drill hole punctures the mine ceiling, allowing water from overlying sources to flow into the mine. Either scenario can cause catastrophic flooding and permanent loss of the mine. Occasionally, a mine that has remained dry for a century will undergo a roof collapse that results in flooding.

\section{Collapses of the Mine Roof}

Until March 1994, the Retsof salt mine in western New York had been the largest active salt mine in North America. It had been in operation for more than 100 years and had a 10-square-mile footprint beneath the Genesee River valley and adjoining uplands to the west (fig. 1). Rock salt (halite) was mined from a salt bed within Silurian shale bedrock as much as 1,100 feet below land surface. Mining was done through a technique called "room-and-pillar" mining, whereby 12-foot-high rooms were excavated within the salt bed, and thick ( 80 feet $\times 80$ feet $)$ salt pillars were left in place to support the mine roof. The mined salt was used mainly as a deicing agent on roadways throughout the northeastern United States.

In 1993, ceiling falls began to occur in rooms in the deepest part of the mine near its southern boundary (fig. 1). In response, the mine owner, AkzoNobel Salt Incorporated (ANSI), turned to an innovative "yielding pillar" mining technique that utilized many narrow ( 20 feet $\times 20$ feet) pillars rather than few wide ones in the mined section. Geotechnical analyses indicated that the resulting configuration would allow the salt pillars to slowly yield and create a "stress envelope" in the surrounding bedrock to support the entire mined room. In November 1993, strain measurements in a yielding-pillar area within the mine 


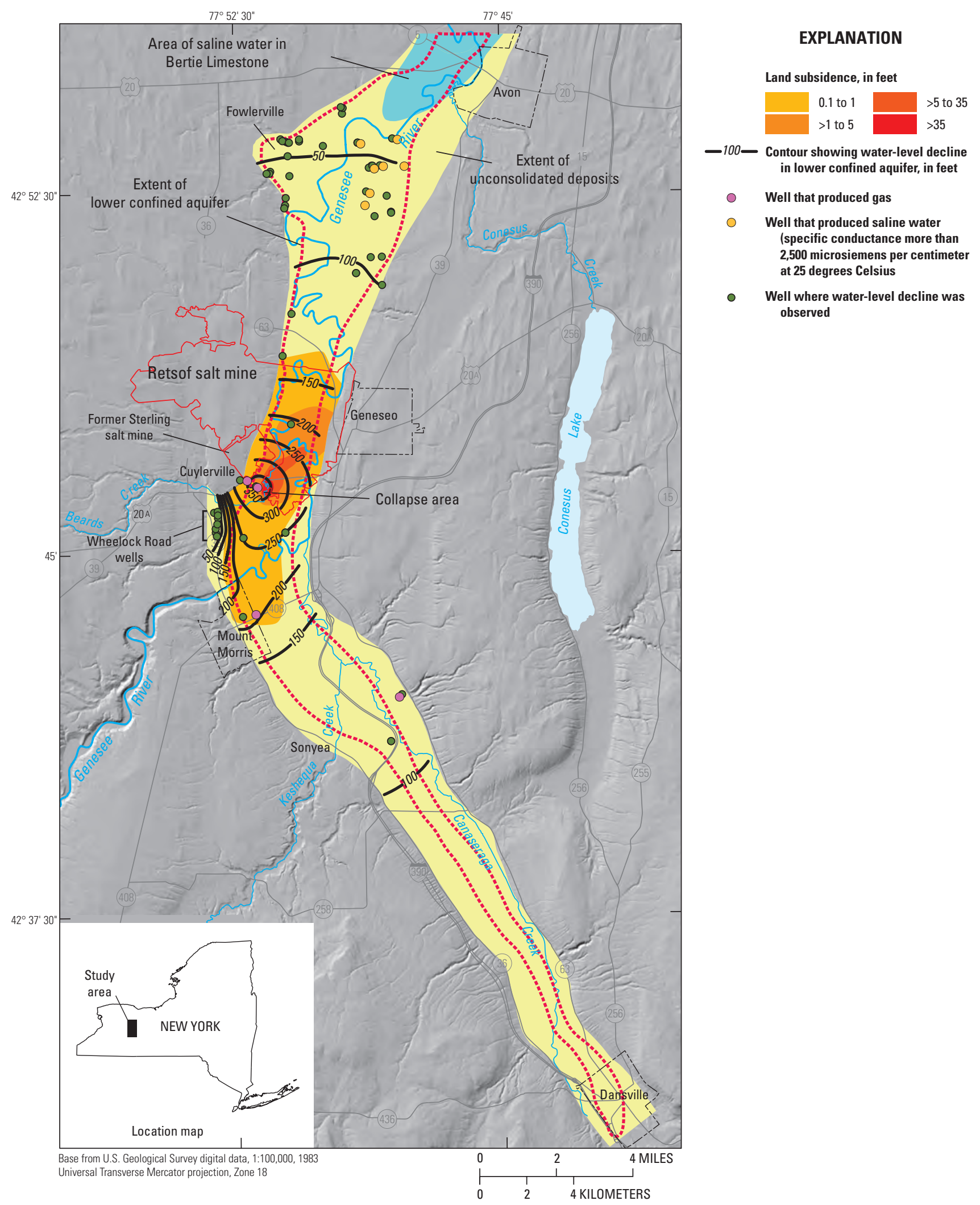

Figure 1. Location of the former Retsof salt mine and area of roof collapse in Livingston County, New York. The extent of the lower confined aquifer is shown, along with the extents of water-level drawdown (depicted as contour lines) and land subsidence (shown by colored shading). The source area of saline water in the Bertie Limestone at the north end of the valley is shown as blue shading. Wells where water levels declined, that produced gas, or became saline are also shown. 
indicated a larger than expected deformation of salt near the eastern wall of room 2 Yard South (fig. 2). Mining in the area was halted as ceiling falls of salt continued during the next 4 months. On March 12, 1994, a magnitude 3.6 seismic event caused by a large collapse was detected by seismometers more than 300 miles away. Mine workers attempted to enter room 2 Yard South and found a pile of rock rubble within the former mined room and saline water entering the mine roof.

Over the next several weeks, ANSI made concerted attempts to save the mine by pumping water out and drilling around the collapse area to inject cement grout to stabilize the collapsed room and prevent further inflow of water. Meanwhile, unstable shale layers overlying room 2 Yard South sagged and collapsed to form a 300-foot-diameter zone of rock rubble that slowly propagated upward through overlying layers of shale. This column of rock rubble is referred to as a rubble chimney.

The propagating rubble chimney eventually reached a layer of carbonate rock that was strong enough to temporarily resist further collapse, stopping further the rubble chimney's upward progression. At this point, the flow of water into the mine stabilized at about 5,500 gallons per minute. The water entering the mine was saline and probably a mixture of saline water from the shale and a prominent fracture zone between the Onondaga and Bertie Limestones (fig. 2). By the end of March 1994, tons of cement grout had been injected into the mine and the rubble chimney through nearly 30 boreholes drilled in the collapse area, but these efforts failed to stem the rate of water flowing into the mine.

On April 6, 1994, the limestone rock layer collapsed, and 550 feet of unconsolidated sediments in the Genesee River valley quickly slumped downward into the resulting cavity, forming a sinkhole at land surface more than 15 feet deep and several hundred feet across. The collapse of the limestone rock was like pulling the plug in a bathtub-it allowed groundwater from a fresh-water aquifer at the base of the unconsolidated sediments (the lower confined aquifer; fig. 2) to drain downwards through the rubble chimney and into the mine. In mid-April, a second collapse occurred in an adjacent room (11 Yard West; fig. 2). On May 25, a drilling crew working above room 11 Yard West felt tremors and removed their drill rig, and themselves, just before a second sinkhole formed at land surface, this one more than 50 feet deep and several hundred feet across. The discharge from the aquifer through both rubble chimneys increased the flow of water into the mine to about 18,000 gallons per minute.

Water began to fill the southern end of the mine and then spread steadily northward, dissolving the bases of the salt pillars that supported the mine ceiling. As the pillars gave way, the southern part of the mine began to collapse, causing the land surface above it to subside. The greatest subsidence (more than 15 feet) was beneath the two sinkholes, which altered the channel of Beards Creek, allowing surface water to fill the sinkholes. The surface water did not flow downward to the mine, however, because hundreds of feet of fine-grained sediments underlie the Genesee River valley. The instability also forced the closure of the U.S. Route 20A bridge over Beards Creek; the southern end of the bridge eventually subsided by 11 feet. The bed of the Genesee River 1 mile north of the collapse areas subsided by as much as 5 feet and altered the pattern of sediment scour and deposition along a 1.5-mile reach downstream of Beards Creek.

\section{Effects of the Mine Roof Collapses}

Among the first residents to feel the effects of the catastrophic failure were the occupants of a farmhouse along Route $20 \mathrm{~A}$ on the opposite side of Beards Creek from the collapse areas. The house became structurally unsafe when the foundation eventually subsided by 3 feet. One week after the initial collapse, domestic wells along Wheelock Road about 1.5 miles southwest of the collapse area began to go dry because water levels in the aquifer suffered large declines over a broad area. By June 1994, water levels had declined by 100 feet in wells as far away as 3 miles south of the collapse area and by as much as 35 feet in wells 8 miles to north (fig. 1).

ANSI began to monitor declines in wells throughout the Genesee River valley and land subsidence as far as 3 miles to the south of the mine. In September 1994, a consulting firm hired by ANSI began a hydrogeologic study that included drilling five boreholes in the valley within 8 miles of the collapse area to characterize the hydraulic properties of the unconsolidated sediments and underlying bedrock. Initial investigations revealed a narrow, buried bedrock valley beneath the Genesee River that extends 25 miles from Avon to Dansville (fig. 1). The deepest part of the bedrock valley, near Sonyea, is 800 feet below land surface. Drill cores from the boreholes revealed that most of the unconsolidated sediments in the valley were deposited during glacial advances and recessions (35,000 to 14,000 years ago), creating a complex system of sediments (fig. 2) that contains three distinct aquifers separated by thick layers of less permeable materials or confining layers (lacustrine clays and tills). The first wells to be affected by the water-level declines drew water from the lower confined aquifer, whereas wells that drew water from the middle aquifer were affected a few days later. Wells in the upper aquifer near land surface were never affected by the mine roof collapses.

The declining water levels in the lower confined aquifer could have resulted in catastrophe in April 1994, when a dry, dewatered well at a hotel in Cuylerville began to produce natural gas (methane) that outgassed from groundwater - much like opening a carbonated beverage container. The natural gas seeped into the basement of the hotel, but was detected and vented before it ignited. By December 1994, two other water wells had also begun to produce natural gas. An analysis of the 


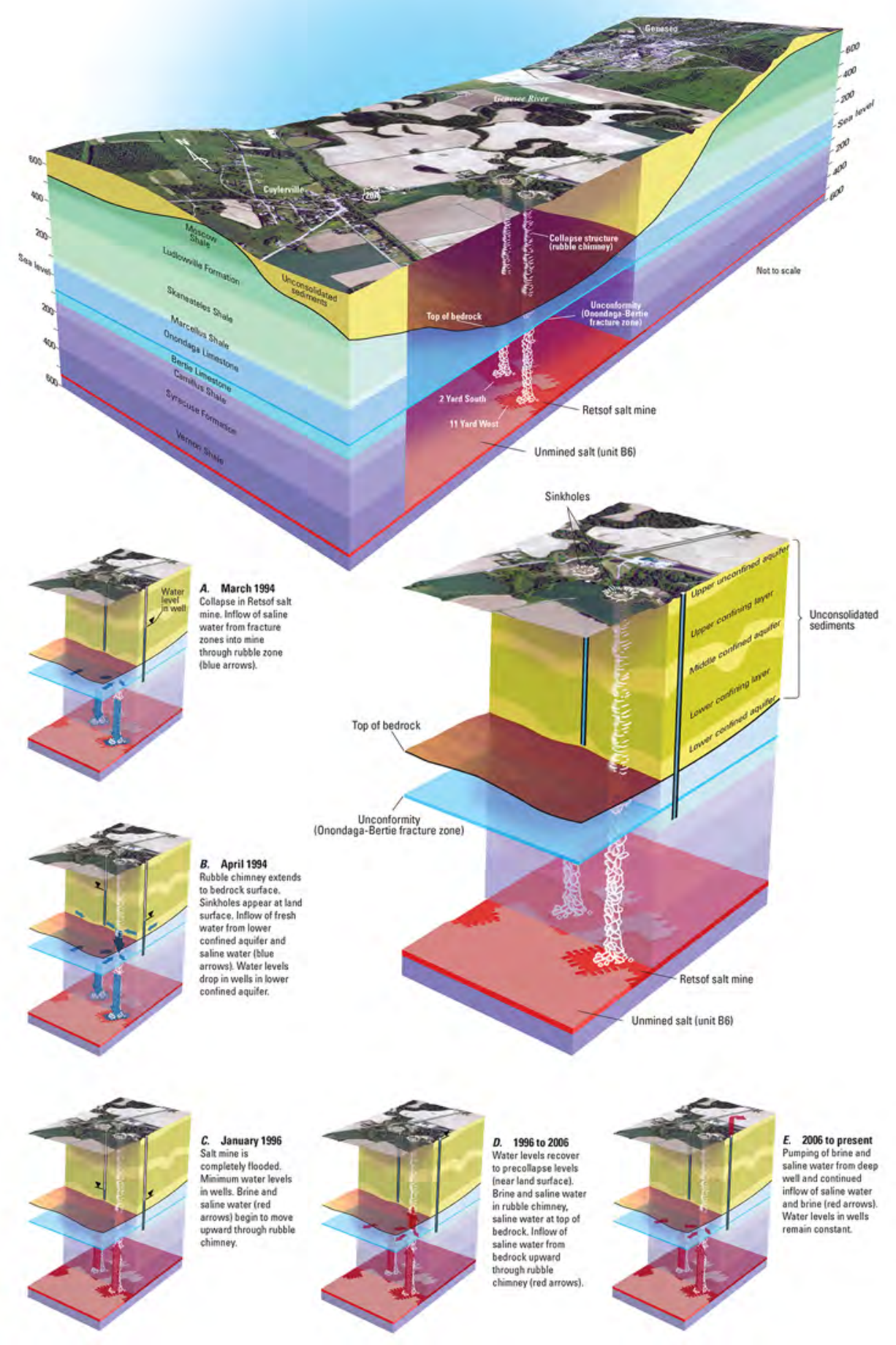

Figure 2. Perspective three-dimensional views showing the geologic setting and the unconsolidated sediments in the area of the Retsof salt mine in Livingston County, New York. Inset views show locations of the rubble chimneys and sinkholes and depict a time sequence of events and movement of waters, including $A$, the roof collapses in Retsof mine in 1994, B, the propagation of rubble chimneys in 1994, C, complete flooding of the salt mine by fresh water from the lower confined aquifer by 1996, D, the recovery of water levels and upward migration of saturated brine from the flooded mine until 2006, and $E$, pumping of saline water and brine from the rubble chimneys after 2006. (http://pubs.usgs.gov/of/2013/1174/pdf/ofr2013-1174_fig2.pdf) 


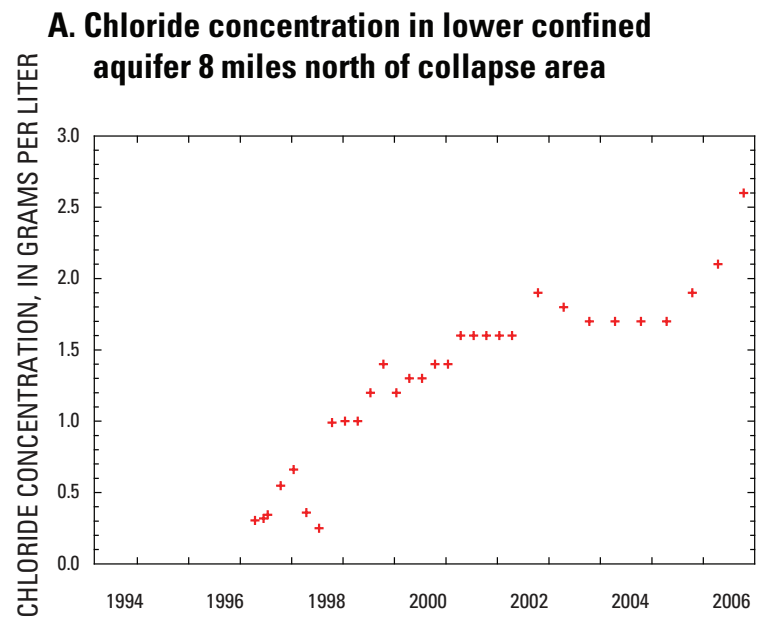

B. Water level in lower confined aquifer

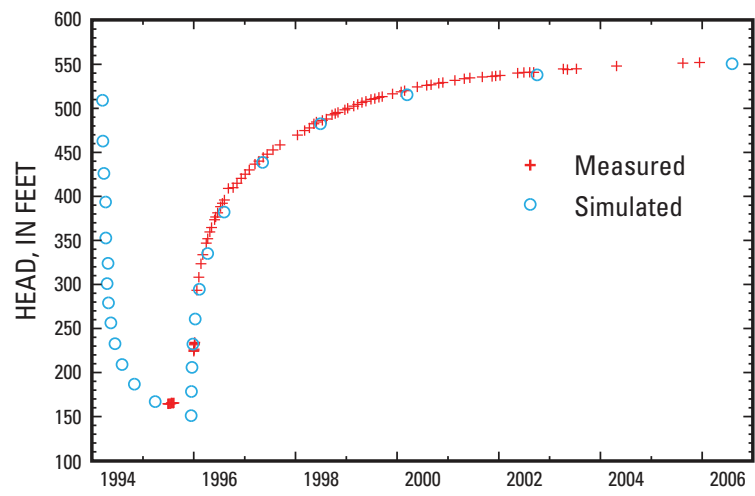

C. Pressure in upper confining layer

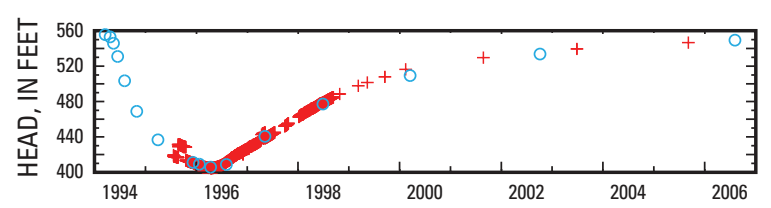

D. Land subsidence 2,800 feet south of collapse area

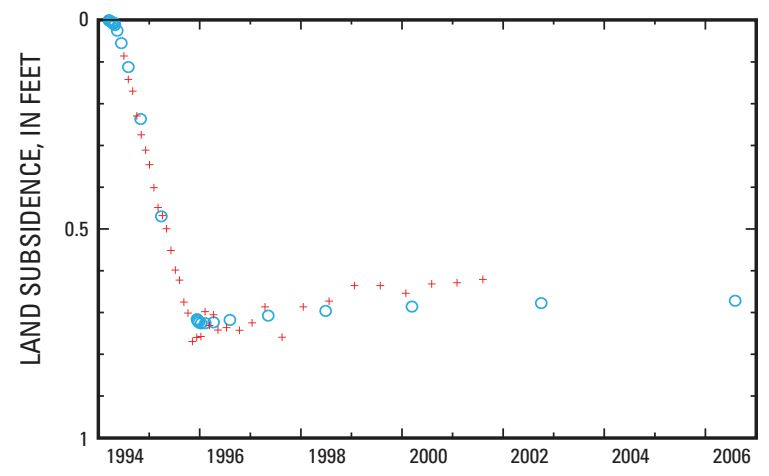

\section{E. Water level in Retsof salt mine}

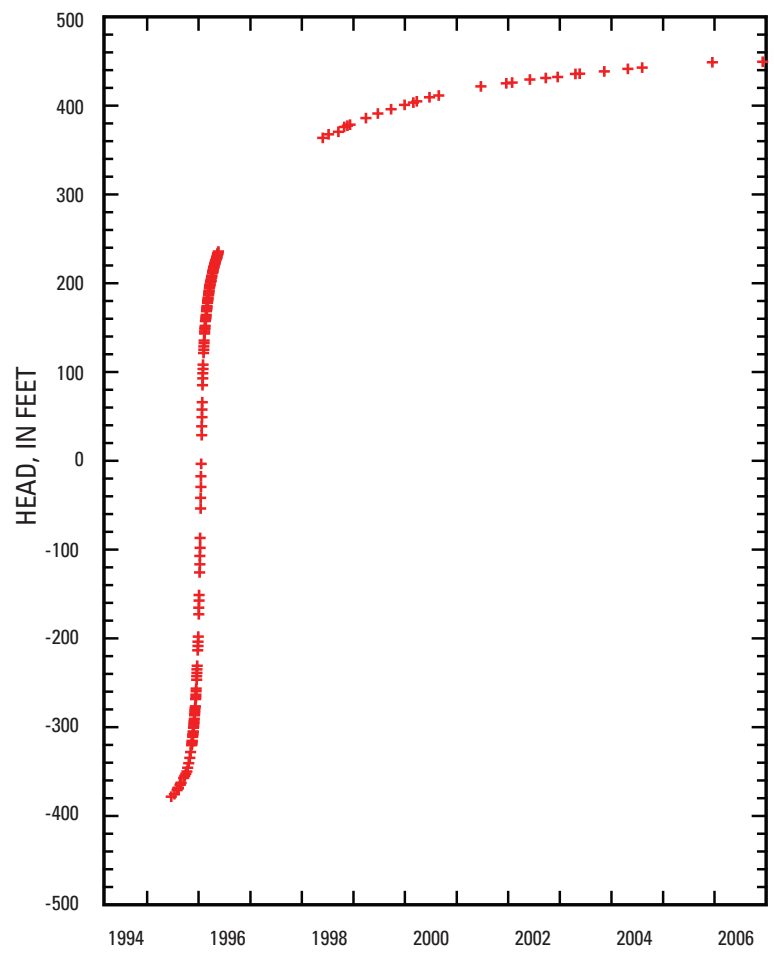

\section{F. Chloride concentration in collapse area}

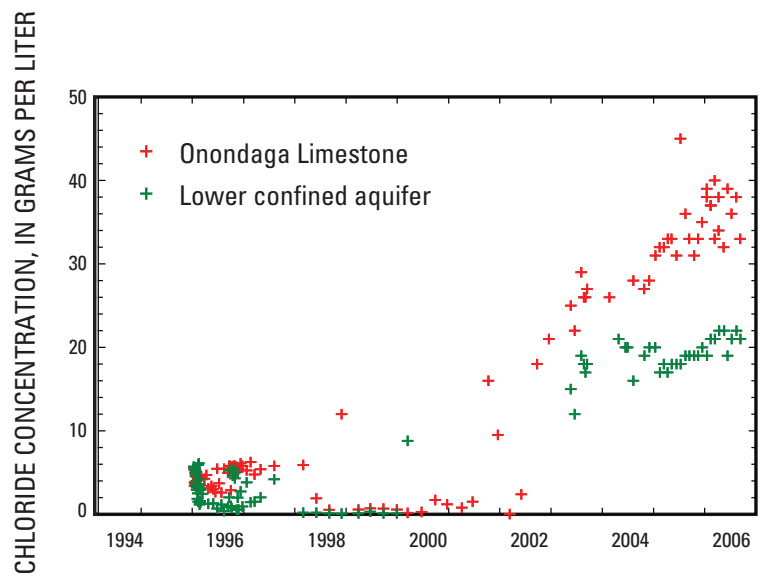

Figure 3. Environmental changes in the aquifer system near the collapsed Retsof salt mine in Livingston County, New York, from 1994 through 2006. $A$, Increase in chloride concentration in a well near Fowlerville indicating increasing salinity. $B$, and $C$, Decrease in water level in the lower confined aquifer and upper confining layer near the collapse area in response to mine flooding and subsequent recovery after the mine was flooded. D, Land subsidence 2,800 feet south of the collapse area that resulted from nonrecoverable compaction of the upper confining layer. $E$, Rise in water level in the mine in response to flooding by fresh water from the lower confined aquifer. $F$, Increase in chloride concentration in the collapse area after the mine was completely flooded in 1996, indicating upward migration of brine and saline water through the rubble chimneys. Measured values are shown in red and values obtained through numerical simulation are shown in blue. 
composition of the gas produced by the water wells indicated a shallow microbial origin. Gas was also produced by wells drilled in the collapse area and proved to have been generated thermally at greater depths and pressures. In May 1995, this thermogenic gas in the collapse area was flared, producing 20-foot-high flames that burned until the mine filled with water in January 1996, 18 months after the initial collapse.

During spring 1995, the chloride concentration (a measure of salinity) of water pumped from five wells in the lower confined aquifer near Fowlerville, 8 miles to the north, increased until the water was no longer potable (fig. 3A). This increase in salinity resulted from the southward movement of saline groundwater from an area underlain by the subcrop area of the Bertie Limestone, a carbonate rock that contains saline water (fig. 1). Water-level decline in the lower confined aquifer had caused the hydraulic gradient in the Fowlerville area to reverse southward, allowing saline water to flow into areas that had previously been potable. The salinity in the five affected wells (expressed as specific conductance) ranged from 2,600 to 13,000 microsiemens per centimeter at 25 degrees Celsius, which was 2 to 10 times the background salinity of 1,300 microsiemens per centimeter at 25 degrees Celsius, and rendered the water nonpotable. Recognizing the threat to wells near Fowlerville, ANSI instituted a groundwater-sampling program and eventually financed a public water-supply system to provide water to the affected residences.

By January 15, 1996, the mine was completely flooded and water levels in the aquifer system began to recover (fig. 3B). Mining operations had ceased in September 1995, and access shafts to the mine were sealed. The maximum drawdowns of water levels in the lower confined aquifer were 400 feet in the collapse area 110 feet near Sonyea, and 50 feet near Fowlerville. Drawdown in the middle aquifer at these locations was similar, except in the collapse area where the maximum drawdown was 250 feet. Nine water wells that had been drilled to the middle aquifer were dry. Wells open to the upper aquifer remained unaffected. As the water levels recovered, the wells that had been producing gas again became filled with water, and the flow of natural gas ceased. Saline water in the lower confined aquifer near Fowlerville continued to migrate southward. Pressure declines caused dewatering and compaction of the thick confining layers that separate the three aquifers (fig. 3C), resulting in land subsidence as much as 0.8 foot about 0.5 mile south of the mine near Mount Morris (fig. 3D). Subsidence above the mine widened the 10-year flood plain of the Genesee River above the mine, increasing it by about 340 acres, and caused channel erosion in this 1.5-mile reach of the Genesee River and in Beards Creek.

\section{First USGS Study}

In 1995, the U.S. Geological Survey (USGS), in cooperation with the Livingston County Department of Health, began a 2-year study to assess the effects of the mine flooding on the aquifer system, predict the time required for water levels in the aquifer system to return to precollapse conditions, and estimate the extent of land subsidence outside the mine area. The study used a computer program to implement a conceptual model of the subsurface and numerically simulate the changes in water levels and movement of groundwater through the aquifer system before and after the mine failure and the compaction of confining-layer sediments. Simulations were calibrated by adjusting the hydraulic properties of aquifers and confining layers to obtain a good match between simulated and observed groundwater levels from their decline in March 1994 until their partial recovery in August 1996.

The simulations indicated the following:

- about 60 percent of the water that flooded the mine was released from storage within the lower confined aquifer;

- water levels in the aquifer system would recover within about 10 years (by 2006);

- the reversal of the hydraulic gradient near Fowlerville caused intrusion of saline water into wells, and salinity would remain high for a decade or more;

- at least 0.1 foot of land subsidence occurred as a result of the compaction of confining-layer sediments within a 16-square-mile area that extended 7 miles south of the mine, and this compaction was largely nonrecoverable; and

- methane that out-gassed from groundwater displaced water from the lower confined aquifer, thereby limiting declines in water levels below those that would have occurred if gas were not present. 


\section{Continuing Concerns}

Environmental concerns regarding the mine failure eased by 1996 as water levels in the aquifer system began to recover and gas releases from wells ceased. Some gas that was trapped in the flooded mine was forced upward by the increasing water pressure and reached land surface at several locations, but these emissions ceased in mid-1996. However, saline-water migration still affected water quality from six wells in the lower confined aquifer in the Fowlerville area. Water-quality monitoring continued at 20 wells, and plans were made to provide drinking water to residents through a public water-supply system. Perhaps the greatest concern was the fate of the 16 billion gallons of saturated salt water that had filled the mine. The water dissolved halite in the mine and had become saturated brine with 10 times the salinity of sea water and a density 20 percent greater than fresh water. The brine-flooded mine remained hydraulically connected to the lower confined aquifer at the two rubble chimneys - connections that had not existed before the collapses.

The plasticity of halite has allowed the unmined salt to deform beneath the weight of overlying rock and sediment and to slowly move into the mined cavity — a phenomenon referred to as "mine squeeze." As the cavity closes, brine is forced upward through the rubble chimneys toward the lower confined aquifer. Geotechnical consultants concluded that the displaced brine would spread laterally through fracture zones in the carbonate rocks before reaching the lower confined aquifer. Another potential concern that native saline water in the fracture zones could be forced upward through the rubble chimneys to the lower confined aquifer was considered unlikely. Although the fracture-zone water is much less saline than brine from the mine, its salinity is comparable to sea water, and incursion by the saline fracture-zone water into the lower confined aquifer could severely impair the quality of groundwater. Because of these concerns, the water level in the mine was monitored (fig. 3E), as was the salinity in the lower confined aquifer and Onondaga Limestone, 35 feet below the bedrock surface within the collapse area.

\section{A New Concern}

Water levels were recorded for 6 years after the mine flooded (1996-2002), during which time the rate of land subsidence decreased consistent with simulation results, and no apparent increase in salinity was detected in the collapse area. Sporadic measurements of substantially increased groundwater salinity in a few samples were discounted as spurious. However, a sharp increase in chloride concentration was indicated in the deeper well in the carbonate unit in 2002 (fig. 3F) and was later confirmed using an improved sampling method. It was later determined that the previous sampling method was flawed, suggesting salinity in the collapse area had actually been increasing before 2002. Moreover, salinity in the lower confined aquifer in the collapse area was now approaching that of sea water. In 2004, ANSI installed five additional wells in the collapse area to monitor salinity and characterize the hydraulic properties of the bedrock. ANSI considered several brine-mitigation options but finally decided to pump saline water and brine from these wells in the collapse area and use thermal (evaporative) desalination to produce salt and fresh water.

Pumping for brine mitigation began in September 2006, by which time water levels in the aquifer system had nearly recovered to their precollapse levels. The salinity profile within the collapse area consisted of a column of saturated halite brine extending from the flooded mine to the Bertie Limestone, at which point, a transition zone of less dense water extended to the lower confined aquifer, where the salinity was nearly that of sea water (fig. 4). The salinity profile included three discontinuities that are correlated with the depths of fracture zones previously detected in borehole geophysical surveys. Two of the fracture zones coincide with stratigraphic contacts between bedrock units; the third is assumed to reflect the presence of a large cavity in shale bedrock. These discontinuities indicated lateral outflow and inflow of water to and from the rubble chimneys in the collapse area. The rate of brine displacement from the mine was initially estimated, from measured rates of land subsidence above the mine, to be 70 gallons per minute. During the next 2 years, pumping rates and depths in the five wells were adjusted to offset inflow of brine from the mine and maintain a stable salinity profile. The final pumping rate was 25 gallons per minute. Except for intermittent shutdowns to remove anhydrite (dehydrated gypsum) deposits from pipes, the desalination plant operated as designed. The sale of salt did not compensate operation costs, however, and the mitigation effort has cost ANSI about $\$ 1$ million per year.

\section{Second USGS Study}

Concurrent with the initiation of the brine-mitigation effort in 2006, the USGS began a second 2-year study, in cooperation with the New York State Office of the Attorney General, to assess the relative contributions from potential sources of salinity in 


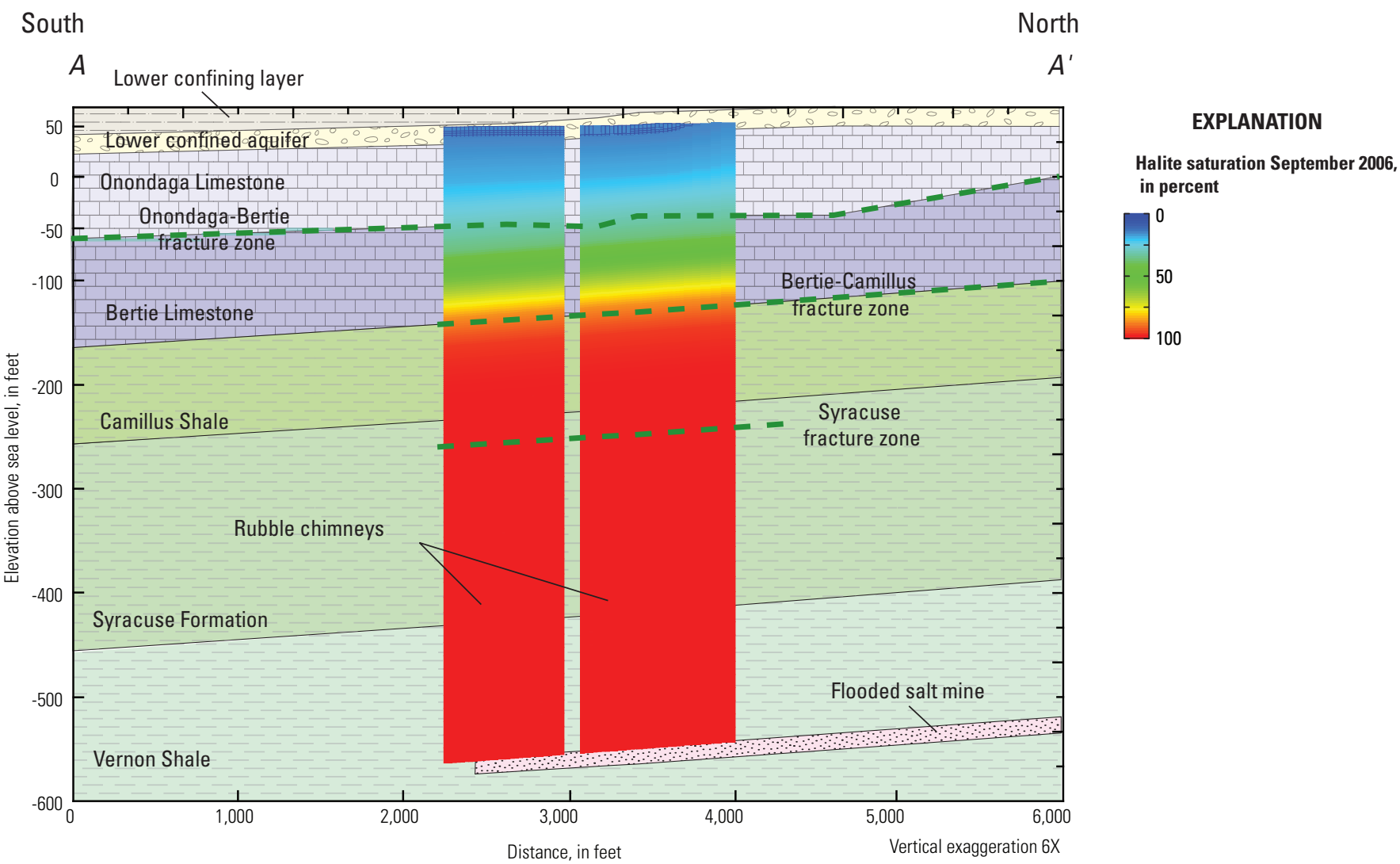

Figure 4. Schematic diagram of the salinity profile along cross-section $A-A^{\prime}$, as percent saturation with respect to halite (sea water is about 10 percent saturation), in the collapse area at the Retsof salt mine in Livingston County, New York, in September 2006. The bedrock stratigraphy and fracture zones are also shown. The lower part of the profile is a column of saturated halite brine. The upper part of the profile (in the Onondaga and Bertie Limestones) is a mixture of brine, saline bedrock water, and fresh water from the lower confined aquifer. Salinity in the lower confined aquifer is primarily a mixture of fresh water and saline bedrock water. Line of section is shown in figure 5 .

the collapse area and whether pumping would be successful in preventing further entry of saline water into the lower confined aquifer. This study used a computer program to implement a groundwater conceptual model that accounted for the variable density of waters within the collapse area that was caused by variations in salinity. Both the movement of brine and saline water during water-level recovery (1996-2006) and the effect of pumping on salinity patterns (2006-08) were simulated. Two rubble chimneys, the zone of deformed bedrock surrounding them, bedrock fracture zones, and a part of the lower confined aquifer were represented in the computer simulations. In addition, geochemical analyses were used to identify the sources of salinity in the collapse area and to assess whether the decreases in water salinity induced by pumping could lead to gypsum dissolution and additional subsidence of the land surface.

The chemical composition of water from several locations and depths in the collapse area indicated that the salinity profile reflected two sources of water: saturated brine from the flooded mine and saline water from fracture zones in the carbonate bedrock. The dense, saturated brine occupied the lower part of the profile and was overlain by a mixture of brine diluted by saline bedrock water and fresh water from the lower confined aquifer. The saline water in the lower confined aquifer appeared to be solely a mixture of fresh water and saline bedrock water. Geochemical simulations indicated that dilution of saturated brine with saline bedrock water would lead to precipitation of anhydrite, as has occurred in the desalination plant. The simulations also predicted little chance of further mineral dissolution as long as fresh water within the rubble chimneys was prevented from flowing downward to depths beneath the carbonate rock. The prevention of mineral dissolution could be ensured if the rate of pumping was consistently lower than the rate of upward brine movement from the flooded mine.

Simulations of the flow of brine and saline water during the 10 years of water-level recovery (1996-2006) indicated that intrusion of saline water into the lower confined aquifer was probably limited to the vicinity of the collapse area and that some 


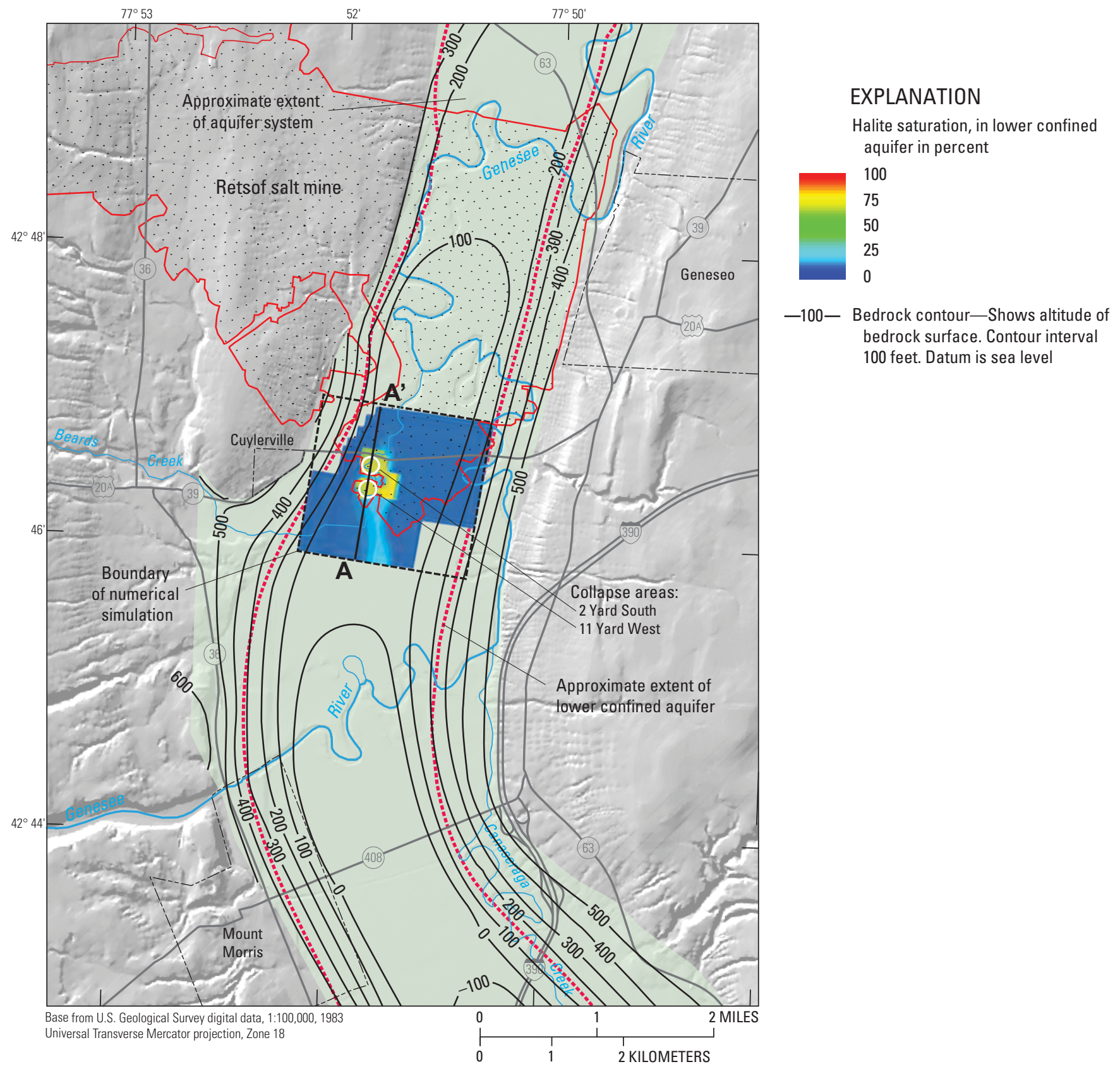

Figure 5. Extent of saline water in the lower confined aquifer 8 years after cessation of pumping in the collapse area as predicted by numerical simulation. Saline water with a density comparable to sea water flows 0.5 mile southward along the sloping bedrock surface and displaces less dense fresh water. The saline water will eventually pool in a depression on the bedrock surface (lower part of diagram) 8 miles south of the collapse area.

lateral diversion of saturated brine into bedrock fracture zones was probable. The fate of the diverted brine cannot be ascertained from the little information available on the extent and hydraulic properties of these zones. Simulations of pumping confirmed that maintaining a combined pumping rate of 25 gallons per minute would prevent further migration of saline water into the lower confined aquifer. However, the simulations also suggested that if pumping were halted, dense saline water would continue to migrate upward to the lower confined aquifer and then southward along the sloping bedrock surface. Model simulations indicated that a plume of water with salinity comparable to that of sea water would extend 0.5 mile south from the collapse area within 8 years (fig. 5). Eventually, the saline water would pool at the lowest point on the bedrock surface, near Sonyea, 8 miles south of the collapse area. 


\section{A Question for the Future}

The current (2013) pumping is preventing further contamination of the lower confined aquifer. However, steady upward flow of saturated brine from the flooded mine is expected to continue for hundreds of years, until the mine cavity closes completely. The volume of brine that could be displaced from the mine - as much as 13 billion gallons - is nearly equivalent to half the volume of water stored in the lower confined aquifer and therefore could render much of the aquifer nonpotable. The cost of the pumping and desalination is more than $\$ 1$ million per year, which could be decreased substantially if a valuable beneficial use could be found for the brine and thereby avoid the need for desalination. For example, the brine could be used directly for road deicing; brine adheres to the road surface and is more efficient in melting snow and ice than rock salt. However, the infrastructure to support storing, transporting and using the brine for this purpose is not widely available.

Ultimate resolution of the salinization threat to the lower confined aquifer will depend on the perceived value of the aquifer, currently a largely untapped resource. The value could include the aquifer's water itself and the aquifer's potential use as a storage reservoir. Simulations of steady-state groundwater flow indicate that pumping 3 million gallons per day from the lower confined aquifer would not affect stream flow or domestic well water levels in the middle and upper aquifers. However, the value of the resource is relative. In upstate New York, water is abundant, and currently water is not pumped directly from the lower confined aquifer. The future value of the aquifer could increase, however, if changes in climate were to lead to decreased recharge in the region or if population growth increased the demand for potable water. On the other hand, the cost of protecting the lower confined aquifer for hundreds of years would be substantial. The State of New York is currently considering relieving ANSI from further responsibility for the control of the brine migration in return for a lump sum payment. If such a settlement is reached, water in much of the lower confined aquifer will eventually become unpotable and the groundwater resource will effectively be abandoned, so the agreement could be considered to be the first "sale" of an aquifer.

\section{Selected References}

Alpha Geoscience, 1996, Geologic and hydrogeologic investigation of the Genesee River valley: Albany, N.Y., Alpha Geoscience, $31 \mathrm{p}$.

Alpha Geoscience, 2005, Comprehensive summary report for the Retsof brine mitigation project: Albany, N.Y., Alpha Geoscience, $45 \mathrm{p}$.

John T. Boyd Company, 1995, Impact analysis_-Retsof mine, Akzo Nobel Salt, Inc.: Pittsburgh, Pa., John T. Boyd Company, $50 \mathrm{p}$.

New York State Department of Environmental Conservation, 1997, Collapse and flooding of Akzo Nobel's Retsof salt mine, Livingston County, New York: Albany, N.Y., Division of Mineral Resources, 113 p.

Shannon and Wilson, Inc., 1995, Task 1 report, Retsof mine collapse, Retsof, New York: Seattle, Wash., Shannon and Wilson, Inc., $20 \mathrm{p}$.

Yager, R.M., Miller, T.S., and Kappel, W.M., 2001, Simulated effects of salt-mine collapse on ground-water flow and land subsidence in a glacial aquifer system, Livingston County, New York: U.S. Geological Survey Professional Paper 1611, 85 p., available at http://pubs.usgs.gov/pp/pp1611/.

Yager, R.M., Miller, T.S., Kappel, W.M., Misut, P.E., Langevin, C.D., Parkhurst, D.L., and deVries, P.M., 2012, Simulated flow of groundwater and brine from a flooded salt mine in Livingston County, New York, and effects of remedial pumping on an overlying aquifer: U.S. Geological Survey Open-File Report 2011-1286, 16 p., available at http://pubs.usgs.gov/ of/2011/1286/.

Yager, R.M., Misut, P.E., Langevin, C.D., and Parkhurst, D.L., 2009, Brine migration from a flooded salt mine in the Genesee Valley, Livingston County, New York-Geochemical modeling and simulation of variable-density flow: U.S. Geological Survey Professional Paper 1767, 59 p., available at http://pubs.usgs.gov/pp/2009/1767/. 
Prepared by the Pembroke Publishing Service Center

For additional information write to:

New York Water Science Center

U.S. Geological Survey

30 Brown $\mathrm{Rd}$

Ithaca, NY 14850

Information requests:

(518) 285-5602

or visit our Web site at: http://ny.water.usgs.gov 
